\title{
Research Note: Effect of CPPU ( $N$-(2-Chloro-4-Pyridinyl)- $N$ '- Phenylurea) and a Seaweed Extract on Flame Seedless, Redglobe and Crimson Seedless Grape Quality
}

\author{
J. Strydom \\ Viticulture Division, ARC Infruitec-Nietvoorbij ${ }^{1}$, Stellenbosch, South Africa \\ Submitted for publication: February 2013 \\ Accepted for publication: April 2013
}

Key words: Acidity, anthocyanin, colour, size, soluble solids

\begin{abstract}
The application of $\mathrm{GA}_{3}$ (gibberellic acid), in combination with CPPU ( $N$-(2-chloro-4-pyridinyl)- $N$ 'phenylurea), may result in larger berries, but also decreases total soluble solids (TSS), increases total titratable acidity (TTA) and reduces grape skin colour. The purpose of this study was to determine a CPPU dosage that would improve berry size, without negative effects on other quality attributes of Flame Seedless, Redglobe and Crimson Seedless. The trials, which were conducted in the 2008/2009 season, comprised five treatments: control (standard $\mathrm{GA}_{3}$ application), seaweed extract plus $\mathrm{GA}_{3}$, and three dosages of CPPU in combination with GA $\mathbf{A}_{3}$. CPPU dosages were 1, 2 and 3 ppm for Flame Seedless; 3, 4 and 5 ppm for Redglobe; and 2, 3 and 4 ppm for Crimson Seedless. The seaweed product used on Flame Seedless and Redglobe was derived from Ascophyllum nodosum, while a derivative of Ecklonia maxima was used on Crimson Seedless. Berry diameter, TSS, TTA, anthocyanin concentration, grape colour as well as cold storage defects were determined. CPPU dosages of 2,5 and 3 ppm significantly increased berry diameter in Flame Seedless, Redglobe and Crimson Seedless respectively. Five ppm CPPU increased Redglobe TSS. Three ppm CPPU increased TTA and decreased anthocyanin concentration in Crimson Seedless. The seaweed extract treatment resulted in firmer Flame Seedless berries with a higher anthocyanin concentration than the control. Seaweed extract also improved the firmness of Crimson Seedless compared to the control. Four ppm CPPU increased the percentage of Crimson Seedless total cold storage defects compared to the control.
\end{abstract}

\section{INTRODUCTION}

The use of CPPU ( $N$-(2-chloro-4-pyridinyl)- $N$ '-phenylurea) on red and black grapes is considered very carefully in South Africa, because it can cause problems with colour development (Anon., 2007). However, some producers use it because an increase in berry diameter may contribute to an increase in yield. When the diameter of Flame Seedless berries is increased from $17 \mathrm{~mm}$ to $18 \mathrm{~mm}$, it can increase the harvest by $21 \%$. Such an increase equals 700 more $4.5 \mathrm{~kg}$ cartons (G.G. van der Merwe, personal communication).

$\mathrm{GA}_{3}$ (gibberellic acid) enlarges the grape berries of cultivars producing seeded and seedless grapes (Zoffoli et al., 2009) and acts synergistically in combination with CPPU to increase berry size even further (Dokoozlian et al., 1994; Zoffoli et al., 2009). Combined applications of $\mathrm{GA}_{3}$ and CPPU (Ben-Arie et al., 1997; Avenant \& Avenant, 2006), as well as CPPU applied on its own (Ben-Arie et al.,
1997), improve grape berry firmness.

Excessive use of CPPU reduces total soluble solids (TSS) and elevates acidity (Dokoozlian et al., 1994). Together, TSS and acidity determine organoleptic acceptability (Lázlo \& Loubser, 1995). Peppi and Fidelibus (2008) found that CPPU can also decrease the amount of anthocyanins per berry skin surface area and cause lighter coloured grape berries.

Seaweed extract, applied as a supplement, has been shown to increase grape berry size (Norrie et al., 2002). With regard to the improvement of grape colour, Redglobe grapes treated with CPPU at véraison, and supplemented with a $1.5 \%$ seaweed solution at $12 \mathrm{~mm}$ and $16 \mathrm{~mm}$ berry size, tended to produce a higher percentage of bunches with a darker colour (Avenant \& Avenant, 2006). The use of a seaweed extract on its own, depending on the dosage, improved the brightness and redness of Trakya Ilkeren grapes (Kok et al., 2010). It has also been documented that several spray applications

\footnotetext{
${ }^{1}$ The Fruit, Vine and Wine Institute of the Agricultural Research Council
} 
of seaweed extract improved berry firmness of Sultanina (Norrie et al., 2002).

The overall objective of this study was to determine whether the cytokinin CPPU and a seaweed product, containing auxins, cytokinins and nutrients, can be included with $\mathrm{GA}_{3}$ as part of the berry enlargement programme in Flame Seedless, Redglobe and Crimson Seedless. The aims were to test the effect of CPPU and a seaweed extract on berry size, as well as the concomitant effects thereof on berry firmness, TSS, TTA (total titratable acidity), anthocyanin concentration and cold storage defects.

\section{MATERIALS AND METHODS}

The experiments were conducted in the 2008/2009 season on Vitis vinifera L. cultivars Flame Seedless and Redglobe in the Northern summer rainfall region (NSR) in the Limpopo province of South Africa, and on Crimson Seedless in the Lower Orange River region (LOR) of the Northern Cape province. The details of the experimental vineyard are depicted in Table 1. Standard viticultural practices for cultivar and region were applied according to guidelines for the preparation of export grapes (Greyling, 2007).

Mean monthly temperature and rainfall data (2008/2009) were obtained from weather stations near Marble Hall in the NSR and at Kanoneiland near Upington in the LOR (Fig. 1). The trials were laid out as randomised complete block designs with five treatments (Table 2), replicated in six blocks with one vine per experimental unit.

The following $\mathrm{GA}_{3}$ (active ingredient $=32 \mathrm{~g} / \mathrm{L}$ gibberellins) thinning and enlargement sprays were applied on Flame Seedless: 5 ppm (110\% flowering), $5 \mathrm{ppm}$ (3 to $4 \mathrm{~mm}$ berry diameter), $10 \mathrm{ppm}$ (7 to $8 \mathrm{~mm}$ berry diameter), $25 \mathrm{ppm}$ ( 8 to $9 \mathrm{~mm}$ berry diameter) and $20 \mathrm{ppm}$ ( 9 to 10 $\mathrm{mm}$ berry diameter). CPPU (active ingredient $=10 \mathrm{~g} / \mathrm{L}$ ) treatments were applied on Flame Seedless as a mixture with $10 \mathrm{ppm} \mathrm{GA}_{3}$ at 7 to $8 \mathrm{~mm}$ berry diameter (Table 2). Aquawet $^{\mathbb{B}}(150 \mathrm{~mL} / 1000 \mathrm{~L})$ was used as wetting agent for all treatments applied to Flame Seedless, except for the seaweed treatment. Redglobe received only one enlargement spray of $25 \mathrm{ppm} \mathrm{GA}$ (active ingredient $=32 \mathrm{~g} / \mathrm{L}$ gibberellins) at 10 to $12 \mathrm{~mm}$ berry diameter. CPPU bunch dip treatments were applied separately without a wetting agent, at 4 to $7 \mathrm{~mm}$ berry diameter. Crimson Seedless received one enlargement spray of $20 \mathrm{ppm} \mathrm{GA}$ (active ingredient $=400 \mathrm{~g} / \mathrm{kg}$ gibberellins) at 6 to $10 \mathrm{~mm}$ berry diameter, applied as a mixture with CPPU treatments. A pH buffer, Bladbuff $5^{\circledR}(250 \mathrm{~mL} / 1000 \mathrm{~L})$, was used for all treatments on Crimson Seedless.

The CPPU and seaweed treatments used in this study were based on the results of commercial trials carried out by agrochemical companies. The choice of seaweed derivative was based on the most widely used product in each particular area. The application of the CPPU and seaweed extract treatments on all three cultivars is summarised in Table 2.

Treatments on Flame Seedless and Crimson Seedless were applied as bunch-directed sprays to ensure full coverage of bunches to the point of run-off (the point at which some of the spray droplets that covered the bunches joined together and began to run over the berries) and the Redglobe bunches were dipped to ensure complete bunch coverage. For the spray treatments, plastic curtains between the vines prevented spray drift. Further details of the applications are presented in Table 2.

According to the maturity indices of the National Department of Agriculture (NDA), the respective minimum total soluble solids (TSS) for Flame Seedless, Redglobe and Crimson Seedless are 15, 14 and $16^{\circ}$ Brix (South Africa, 1990). When average berry TSS for each cultivar reached minimum export requirements, 50 berries were sampled randomly from each experimental vine. Ten randomly selected bunches from each of the data vines of each cultivar were harvested, weighed and packed for cold storage. Bunches were individually packed in carry bags inside $4.5 \mathrm{~kg}$ closed-top cartons lined with a perforated plastic bag. A UVASYS ${ }^{\circledR}$ dual release sulphur dioxide $\left(\mathrm{SO}_{2}\right)$ generator

\section{TABLE 1}

Details of the Flame Seedless, Redglobe and Crimson Seedless vineyards.

\begin{tabular}{|c|c|c|c|}
\hline \multirow{2}{*}{ Parameters } & \multicolumn{3}{|c|}{ Cultivar } \\
\hline & Flame Seedless & Redglobe & Crimson Seedless \\
\hline Production region & Northern summer rainfall & Northern summer rainfall & Lower Orange River \\
\hline Locality & $\begin{array}{l}\text { Tebogo } \\
\text { (commercial farm near Marble Hall) } \\
\text { Limpopo province }\end{array}$ & $\begin{array}{l}\text { Tebogo } \\
\text { (commercial farm near Marble Hall) } \\
\text { Limpopo province }\end{array}$ & $\begin{array}{l}\text { Roepersfontein } \\
\text { (commercial farm near Upington) } \\
\text { Northern Cape province }\end{array}$ \\
\hline Rootstock & $\mathrm{R} 110($ V. berlandieri $x$ V. rupestris) & Ramsey (V. champinii) & Ramsey (V. champinii) \\
\hline Year planted & 1999 & 1999 & 2004 \\
\hline Soil type & Sand & Sand & Sand \\
\hline Irrigation system & Drip & Drip & Micro \\
\hline Planting width & $3.5 \mathrm{~m} \mathrm{x} 1.6 \mathrm{~m}$ & $3.5 \mathrm{mx} 1.6 \mathrm{~m}$ & $3.0 \mathrm{~m} \mathrm{x} 2.5 \mathrm{~m}$ \\
\hline No vines/ha & 1800 & 1800 & 1333 \\
\hline Trellis system & Gable with hail netting & Gable with hail netting & Pergola \\
\hline Week of bud break & Week 32 & Week 34 & Week 37 \\
\hline Harvest date & $2008-11-27$ & $2008-12-23$ & 2009-02-03 \\
\hline Pruning system & $\begin{array}{l}8 \text { half-long and } \\
18 \text { spurs/vine } \\
(136800 \text { buds/ha) }\end{array}$ & $\begin{array}{l}10 \text { half-long bearers and } \\
16 \text { spurs/vine } \\
\text { (194 } 400 \text { buds/ha) }\end{array}$ & $\begin{array}{l}10 \text { half-long bearers/vine } \\
(160000 \mathrm{buds} / \mathrm{ha})\end{array}$ \\
\hline
\end{tabular}




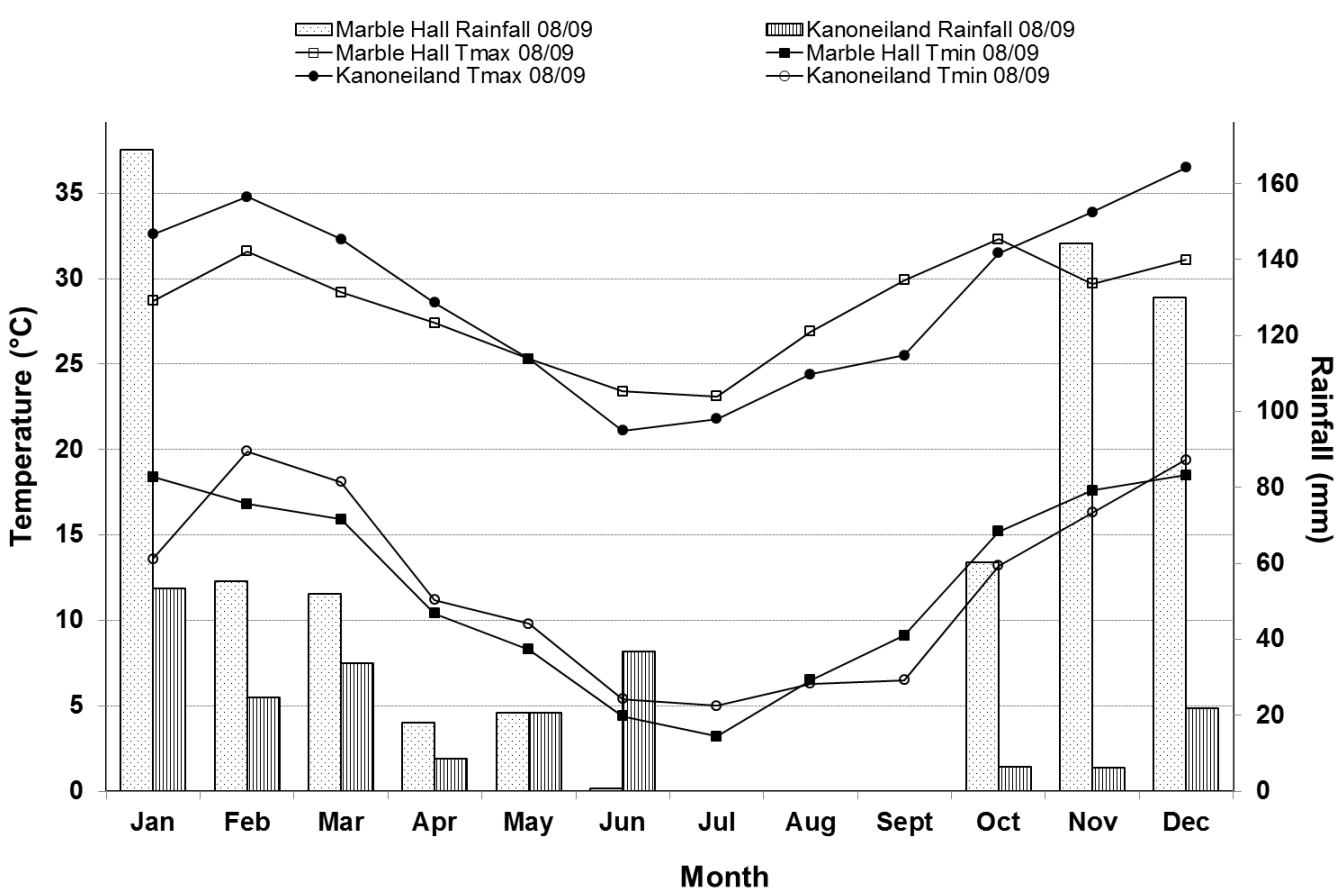

FIGURE 1

Mean monthly temperature and rainfall for Marble Hall in Limpopo province and Kanoneiland near Upington in the Northern Cape province (2008/2009 season), South Africa (ARC-ISCW, 2008). Tmax = mean monthly maximum temperature; Tmin $=$ mean monthly minimum temperature.

TABLE 2

Treatments applied to Flame Seedless, Redglobe and Crimson Seedless at two localities (2008/2009).

\begin{tabular}{|c|c|c|c|}
\hline \multirow[t]{5}{*}{ Treatment* } & \multicolumn{3}{|c|}{ Dosage and application time (phenological stage/berry diameter) } \\
\hline & \multicolumn{3}{|c|}{ Cultivar and locality } \\
\hline & Flame Seedless & Redglobe & Crimson Seedless \\
\hline & Tebogo & Tebogo & Roepersfontein \\
\hline & Limpopo Province & Limpopo Province & Northern Cape Province \\
\hline Control & - & - & - \\
\hline${ }^{a} \mathrm{CPPU}$ & $1 \mathrm{ppm}$ at $7-8 \mathrm{~mm}$ & $3 \mathrm{ppm}$ at $4-7 \mathrm{~mm}$ & $2 \mathrm{ppm}$ at $6-10 \mathrm{~mm}$ \\
\hline${ }^{a} \mathrm{CPPU}$ & $2 \mathrm{ppm}$ at $7-8 \mathrm{~mm}$ & $4 \mathrm{ppm}$ at $4-7 \mathrm{~mm}$ & $3 \mathrm{ppm}$ at $6-10 \mathrm{~mm}$ \\
\hline${ }^{a} \mathrm{CPPU}$ & $3 \mathrm{ppm}$ at $7-8 \mathrm{~mm}$ & $5 \mathrm{ppm}$ at $4-7 \mathrm{~mm}$ & $4 \mathrm{ppm}$ at $6-10 \mathrm{~mm}$ \\
\hline${ }^{b}$ Seaweed extract & $\begin{array}{l}0.2 \%(\mathrm{v} / \mathrm{v}) \text { at } 4-6 \mathrm{~mm}, 8-10 \mathrm{~mm} \text {, } \\
9-11 \mathrm{~mm}\end{array}$ & $\begin{array}{l}0.2 \%(\mathrm{v} / \mathrm{v}) \text { at } 85 \% \text { flowering, } \\
4-7 \mathrm{~mm}, 8-16 \mathrm{~mm}\end{array}$ & $\begin{array}{l}0.3 \%(\mathrm{v} / \mathrm{v}) \text { at } 50 \% \text { flowering, } \\
1-4 \mathrm{~mm}, 6-10 \mathrm{~mm}, 12-15 \mathrm{~mm} \text {, } \\
15-16 \mathrm{~mm}\end{array}$ \\
\hline
\end{tabular}

*All treatments received recommended $\mathrm{GA}_{3}$ thinning and enlargement sprays

${ }^{a} N$-(2-chloro-4-pyridinyl)- $N$ '-phenylurea

${ }^{b}$ derivative of Ascophyllum nodosum (Auxins/Cytokinins: 22/15 mg/L) used on Flame Seedless and Redglobe and derivative of Ecklonia maxima (Auxins/Cytokinins: 11/0.031 mg/L) used on Crimson Seedless

sheet (Grapetek, South Africa) was positioned on top of the grapes.

The sampled berries were used to determine berry diameter, visual grape colour, as well as TSS, TTA (total titratable acidity) and anthocyanin concentration. Grape colour was determined visually by classification of bunches and berries into different colour classes, from 1 (dark) to 9 (light) according to the respective cultivar colour charts of the NDA (South Africa, 1990). TSS were determined with a digital hand-held refractometer (Atago dbx-30) and expressed as ${ }^{\circ}$ Brix. TTA $(\mathrm{g} / \mathrm{L})$ was determined by titration of a $50 \mathrm{~mL}$ filtered juice sample with $0.333 \mathrm{~N} \mathrm{NaOH}$ to a
$7 \mathrm{pH}$ end-point using an automatic titrator (Mettler Toledo DL15). The anthocyanin concentration of the whole berries was determined by spectrophotometry (Thermospectronic He $\lambda$ ios Gamma) according to the method of Iland et al. (2000), and expressed as $\mathrm{mg}$ anthocyanins/g fresh berry weight (FW).

After five weeks in cold storage at $-0.5^{\circ} \mathrm{C}$, followed by one week at $7.5^{\circ} \mathrm{C}$, evaluations for loose berries, $\mathrm{SO}_{2}$ damage, berry crack, decay, soft tissue breakdown and external bruises were carried out. Thirty randomly sampled berries were used to determine berry firmness with the Isicudisi Grape and Soft Fruit Compression Tester (Central Electronic 
Services, Stellenbosch University). The force needed to press the pressure probe onto the berry skin surface at a press setting of $1 \mathrm{~mm}$, without penetrating the skin, was expressed as g. High values present firmer berries.

Colour chart classification data were subjected to a general linear model (GLM) technique with a logistic link function. The maximum likelihood estimators (X-beta's) were calculated on an underlying scale (McCullagh \& Nelder, 1989). These estimators, which are on an interval scale, were subjected to standard two-way analysis of variance (ANOVA). The cut-off points for the respective classes were given as intercepts. For all the data, the Shapiro-Wilk test was performed to test for normality (Shapiro \& Wilk, 1965). Student's t-least significant differences (LSD) were calculated at a 5\% significance level to facilitate comparison between the treatment means.

\section{RESULTS AND DISCUSSION \\ Berry size and berry firmness \\ Flame Seedless}

Two ppm CPPU significantly increased berry diameter compared to the control, but did not affect berry firmness significantly (Table 3). Berries from the control treatment were significantly firmer than berries from 1 and $3 \mathrm{ppm}$ CPPU. Flame Seedless berries produced by the seaweed extract treatment were significantly smaller than berries from the control and CPPU treatments.

\section{Redglobe}

In comparison with the control, 5 ppm CPPU significantly increased berry diameter, whereas none of the treatments affected berry firmness significantly (Table 4).

\section{Crimson Seedless}

Compared to the control, berry diameter was significantly increased by 3 and 4 ppm CPPU (Table 5). Compared to the seaweed extract treatment, all the CPPU treatments increased berry diameter. Compared to the control, berry firmness was not significantly affected by CPPU. Firmness was significantly increased by the treatment with seaweed extract.

Increased berry size when a synthetic cytokinin is used in combination with $\mathrm{GA}_{3}$ (Dokoozlian et al., 1994; Zoffoli et al., 2009) was confirmed in this study. However, the results obtained on berry firmness are contradictory to results from previous work on other cultivars. In this study, the control $\left(\mathrm{GA}_{3}\right.$ standard) produced firmer Flame Seedless berries than 1 and 3 ppm CPPU (in combination with the standard $\mathrm{GA}_{3}$ treatment), whereas Ben-Arie et al. (1997) found that $\mathrm{GA}_{3}$ in combination with CPPU increased berry firmness of Superior. This contradiction might be explained by the different reactions of cultivars to synthetic cytokinins. In the Redglobe trial, CPPU did not have a significant effect on berry firmness when CPPU was applied at 4 to $7 \mathrm{~mm}$ berry diameter, whereas Avenant and Avenant (2006) found that Redglobe berry firmness increased when CPPU was applied at véraison only. This contradiction can be attributed to the

TABLE 3

Effect of treatments on berry size and grape quality variables of Flame Seedless from Tebogo in Limpopo province (2008/2009).

\begin{tabular}{|c|c|c|c|c|c|}
\hline Treatment & $\begin{array}{l}\text { Berry diameter } \\
\qquad(\mathrm{mm})\end{array}$ & $\begin{array}{l}\text { Berry firmness } \\
\text { after cold storage } \\
(\mathrm{g})\end{array}$ & $\begin{array}{l}\text { Total soluble } \\
\text { solids ( }{ }^{\circ} \text { Brix) }\end{array}$ & $\begin{array}{l}\text { Total titratable } \\
\text { acidity }(\mathrm{g} / \mathrm{L})\end{array}$ & $\begin{array}{c}\text { Anthocyanin } \\
\text { concentration } \\
\left(\mathrm{mg} / \mathrm{g} \mathrm{FW}^{a}\right)\end{array}$ \\
\hline Control & $19.51 b^{*}$ & $132.61 \mathrm{a}$ & $16.15 \mathrm{ab}$ & $5.07 \mathrm{~b}$ & $0.13 \mathrm{~b}$ \\
\hline $1 \mathrm{ppm} \mathrm{CPPU}^{b}$ & $19.57 \mathrm{~b}$ & $118.10 \mathrm{~b}$ & $15.47 \mathrm{bc}$ & $5.18 \mathrm{ab}$ & $0.15 \mathrm{ab}$ \\
\hline $2 \mathrm{ppm} \mathrm{CPPU}^{b}$ & $20.02 \mathrm{a}$ & $129.27 \mathrm{ab}$ & $16.02 \mathrm{bc}$ & $5.16 \mathrm{ab}$ & $0.09 \mathrm{~b}$ \\
\hline $3 \mathrm{ppm} \mathrm{CPPU}^{b}$ & $19.84 \mathrm{ab}$ & $117.75 \mathrm{~b}$ & $15.38 \mathrm{c}$ & $5.23 \mathrm{a}$ & $0.09 \mathrm{~b}$ \\
\hline Seaweed extract & $18.62 \mathrm{c}$ & $136.73 \mathrm{a}$ & $16.85 \mathrm{a}$ & $5.29 \mathrm{a}$ & $0.20 \mathrm{a}$ \\
\hline
\end{tabular}

*Means with the same letter in each column did not differ significantly $(P=0.05)$

${ }^{a} \mathrm{FW}=$ Fresh berry weight

${ }^{b} N$-(2-chloro-4-pyridinyl)- $N$ '-phenylurea

TABLE 4

Effect of treatments on berry size and grape quality variables of Redglobe from Tebogo in Limpopo province (2008/2009).

\begin{tabular}{lccccc}
\hline Treatment & $\begin{array}{c}\text { Berry diameter } \\
(\mathrm{mm})\end{array}$ & $\begin{array}{c}\text { Berry firmness } \\
\text { after cold storage } \\
(\mathrm{g})\end{array}$ & $\begin{array}{c}\text { Total soluble } \\
\text { solids }\left({ }^{\circ} \mathrm{Brix}\right)\end{array}$ & $\begin{array}{c}\text { Total titratable } \\
\text { acidity }(\mathrm{g} / \mathrm{L})\end{array}$ & $\begin{array}{c}\text { Anthocyanin } \\
\text { concentration } \\
(\mathrm{mg} / \mathrm{g} \mathrm{FW})\end{array}$ \\
\hline Control & $24.54 \mathrm{~b}^{*}$ & $95.17 \mathrm{a}$ & $13.28 \mathrm{~b}$ & $5.29 \mathrm{a}$ & $0.13 \mathrm{ab}$ \\
$3 \mathrm{ppm} \mathrm{CPPU}^{b}$ & $25.25 \mathrm{ab}$ & $102.11 \mathrm{a}$ & $13.22 \mathrm{~b}$ & $5.19 \mathrm{a}$ & $0.11 \mathrm{~b}$ \\
$4 \mathrm{ppm} \mathrm{CPPU}^{b}$ & $25.14 \mathrm{ab}$ & $97.80 \mathrm{a}$ & $13.85 \mathrm{ab}$ & $5.19 \mathrm{a}$ & $0.14 \mathrm{ab}$ \\
5 ppm CPPU $^{b}$ & $25.52 \mathrm{a}$ & $102.28 \mathrm{a}$ & $13.93 \mathrm{a}$ & $5.12 \mathrm{a}$ & $0.15 \mathrm{a}$ \\
Seaweed extract $^{b}$ & $24.58 \mathrm{~b}$ & $103.81 \mathrm{a}$ & $13.70 \mathrm{ab}$ & $5.25 \mathrm{a}$ & $0.15 \mathrm{a}$ \\
\hline
\end{tabular}

*Means with the same letter in each column did not differ significantly $(P=0.05)$

${ }^{a} \mathrm{FW}=$ Fresh berry weight

${ }^{b} N$-(2-chloro-4-pyridinyl)- $N$ '-phenylurea 
application time and thus purpose of CPPU application. In this study, the purpose of application was to increase Redglobe berry size, whereas the purpose of the study of Avenant and Avenant (2006) was to manipulate Redglobe berry colour.

Juice composition, grape colour and anthocyanin concentration

\section{Flame Seedless}

Three ppm CPPU lowered TSS and increased TTA compared to the control, whereas 2 ppm CPPU did not have a significant effect on these variables (Table 3). None of the CPPU treatments had a significant effect on anthocyanin concentration. The seaweed extract significantly increased anthocyanin concentration compared to the control.

\section{Redglobe}

Compared to the control, TSS was significantly increased by 5 ppm CPPU, whereas TTA and anthocyanin concentration were not affected significantly (Table 4).

\section{Crimson Seedless}

Compared to the control, TSS was significantly decreased by $4 \mathrm{ppm}$ CPPU. All the CPPU treatments significantly increased TTA and significantly decreased anthocyanin concentration compared to the control (Table 5).

Lowered TSS, increased TTA (Dokoozlian et al., 1994; Zoffoli et al., 2009) and lowered anthocyanin concentration (Peppi \& Fidelibus, 2008) due to CPPU were confirmed in this study. Increased TTA is sometimes related to a delay in harvest. However, according to the maturity indices of the NDA (South Africa, 1990), a minimum value of $16^{\circ}$ Brix is required for Crimson Seedless and, in this study, $3 \mathrm{ppm}$ CPPU resulted in a TSS of $18^{\circ}$ Brix and higher. The results of the visual colour classification of the berries followed similar patterns (Figs 2 to 4 ) to the anthocyanin concentration. The Flame Seedless and Crimson Seedless bunches from all treatments were suitable for export (data not shown).

CPPU only had a negative effect on the anthocyanin concentration of Crimson Seedless in the LOR. The more pronounced effect of CPPU on anthocyanin concentration in

TABLE 5

Effect of treatments on berry size and grape quality variables of Crimson Seedless from Roepersfontein in the Northern Cape province $(2008 / 2009)$.

\begin{tabular}{lccccc}
\hline Treatment & $\begin{array}{c}\text { Berry diameter } \\
(\mathrm{mm})\end{array}$ & $\begin{array}{c}\text { Berry firmness } \\
\text { after cold storage } \\
(\mathrm{g})\end{array}$ & $\begin{array}{c}\text { Total soluble } \\
\text { solids }\left({ }^{\circ} \mathrm{Brix}\right)\end{array}$ & $\begin{array}{c}\text { Total titratable } \\
\text { acidity }(\mathrm{g} / \mathrm{L})\end{array}$ & $\begin{array}{c}\text { Anthocyanin } \\
\text { concentration } \\
(\mathrm{mg} / \mathrm{g} \mathrm{FW})\end{array}$ \\
\hline Control & $18.50 \mathrm{bc}^{*}$ & $107.91 \mathrm{~b}$ & $18.95 \mathrm{a}$ & $5.39 \mathrm{~b}$ & $0.26 \mathrm{a}$ \\
2 ppm CPPU $^{b}$ & $19.27 \mathrm{ab}$ & $117.93 \mathrm{ab}$ & $18.47 \mathrm{a}$ & $5.84 \mathrm{a}$ & $0.17 \mathrm{~b}$ \\
3 ppm CPPU $^{b}$ & $19.62 \mathrm{a}$ & $117.21 \mathrm{ab}$ & $18.37 \mathrm{ab}$ & $5.70 \mathrm{a}$ & $0.18 \mathrm{~b}$ \\
4 ppm CPPU $^{b}$ & $19.68 \mathrm{a}$ & $114.06 \mathrm{ab}$ & $17.32 \mathrm{~b}$ & $5.96 \mathrm{a}$ & $0.17 \mathrm{~b}$ \\
Seaweed extract & $18.38 \mathrm{c}$ & $120.01 \mathrm{a}$ & $19.17 \mathrm{a}$ & $5.36 \mathrm{~b}$ & $0.25 \mathrm{a}$ \\
\hline
\end{tabular}

*Means with the same letter in each column did not differ significantly $(P=0.05)$

${ }^{a} \mathrm{FW}=$ Fresh berry weight

${ }^{b} N$-(2-chloro-4-pyridinyl)- $N$ '-phenylurea

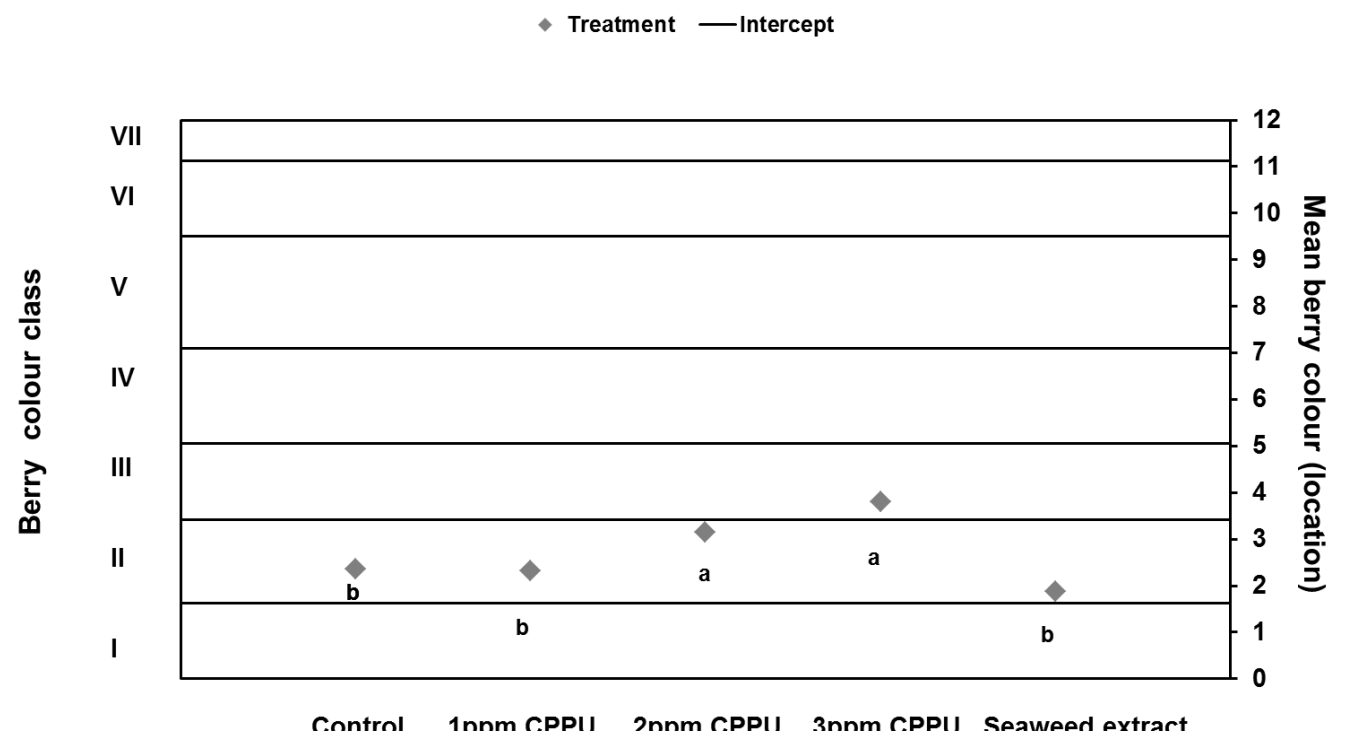

Treatment

FIGURE 2

The effect of CPPU and a seaweed extract on the visual colour of Flame Seedless berries from Tebogo in Limpopo province in the 2008/2009 season (significance of differences at $\mathrm{P}=0.05$ indicated with letters). 
the LOR was probably due to high temperatures of above $30^{\circ} \mathrm{C}$. Above $30^{\circ} \mathrm{C}$, anthocyanin biosynthesis is reduced (Mori et al., 2005) and anthocyanin pigments are degraded (Mori et al., 2007). During the ripening period of Crimson Seedless (December to February), maximum temperatures rose above $30^{\circ} \mathrm{C}$ in the LOR (Fig. 1). Thus the reduction in anthocyanin concentration might also be related to high temperatures during the ripening period.

\section{Cold storage defects}

Data obtained from evaluations after cold storage showed some trends, although these were not always specific or significant. Compared to the control, the percentage total cold storage defects of Flame Seedless and Redglobe were not affected by any of the treatments (Tables 6 and 7). An increase in CPPU dosage tended to increase the percentage of $\mathrm{SO}_{2}$ damage, bruises and total defects of Crimson Seedless compared to the control, whereas 4 ppm CPPU increased

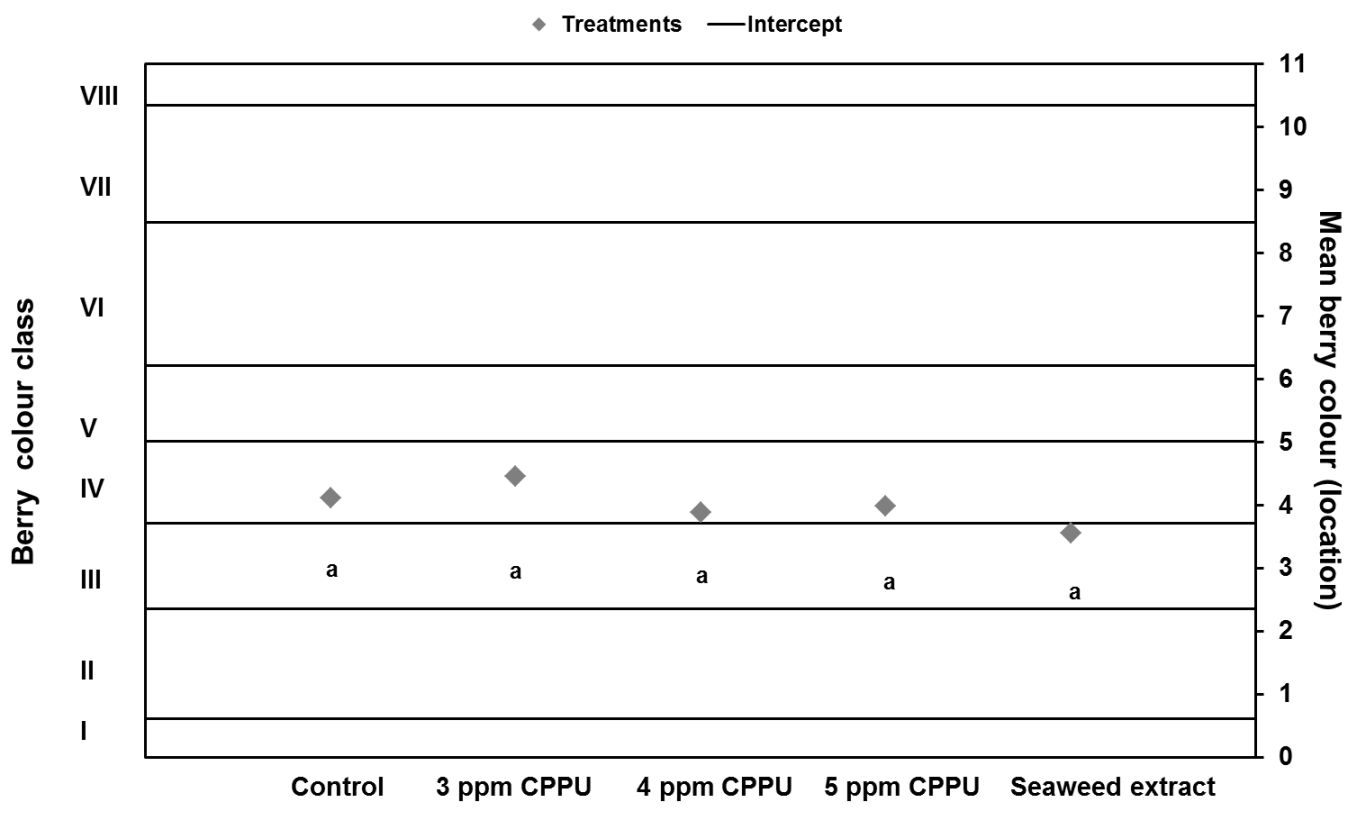

Treatment

FIGURE 3

The effect of CPPU and a seaweed extract on the visual colour of Redglobe berries from Tebogo in Limpopo province in the $2008 / 2009$ season (significance of differences at $\mathrm{P}=0.05$ indicated with letters).

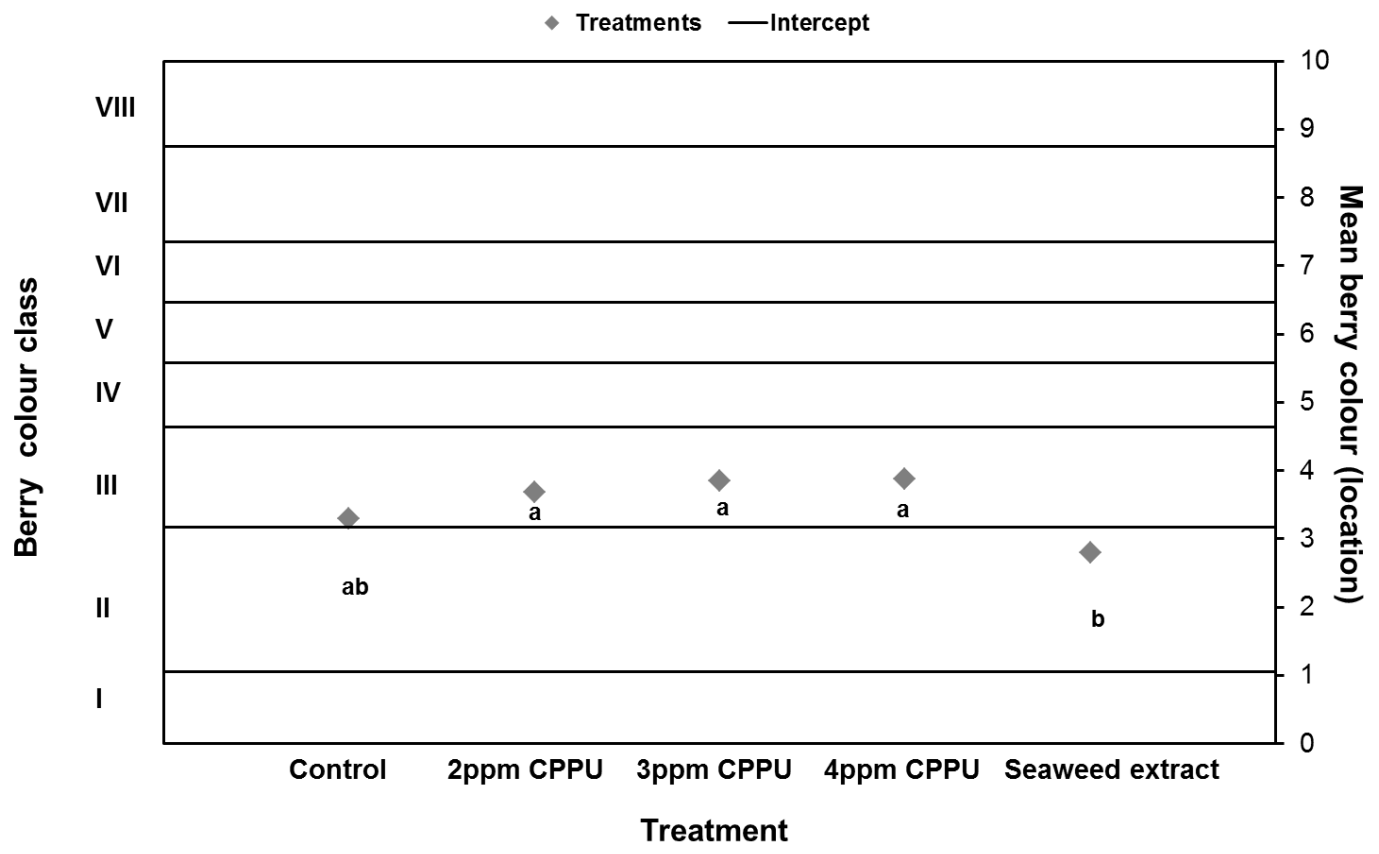

FIGURE 4

The effect of CPPU and a seaweed extract on the visual colour of Crimson Seedless berries from Roepersfontein in the Northern Cape province in the 2008/2009 season (significance of differences at $\mathrm{P}=0.05$ indicated with letters). 
TABLE 6

Effect of treatments on defects of Flame Seedless from Tebogo in Limpopo province after six weeks (five weeks at $-0.5^{\circ} \mathrm{C}$ plus one week at $\left.7.5^{\circ} \mathrm{C}\right)$ of cold storage $(2008 / 2009)$.

\begin{tabular}{|c|c|c|c|c|c|c|c|}
\hline Treatment & $\begin{array}{c}\text { Total loose } \\
\text { berries } \\
(\%)\end{array}$ & $\mathrm{SO}_{2}$ damage & $\begin{array}{c}\text { Decay } \\
(\%)\end{array}$ & $\begin{array}{c}\text { Split berries } \\
(\%)\end{array}$ & $\begin{array}{c}\text { Soft tissue } \\
\text { breakdown } \\
(\%)\end{array}$ & $\begin{array}{c}\text { Bruises } \\
(\%)\end{array}$ & $\begin{array}{c}\text { Total } \\
\text { defects } \\
(\%)\end{array}$ \\
\hline Control & $2.08 \mathrm{ab}^{*}$ & $0.27 \mathrm{~b}$ & $0.04 \mathrm{a}$ & $1.19 \mathrm{a}$ & $0.17 \mathrm{a}$ & $0.02 \mathrm{a}$ & $3.77 \mathrm{ab}$ \\
\hline $1 \mathrm{ppm} \mathrm{CPPU}^{a}$ & $1.38 \mathrm{~b}$ & $1.10 \mathrm{a}$ & $0.04 \mathrm{a}$ & $1.23 \mathrm{a}$ & $0.47 \mathrm{a}$ & $0.00 \mathrm{a}$ & $4.22 \mathrm{ab}$ \\
\hline $2 \mathrm{ppm} \mathrm{CPPU}^{a}$ & $1.38 \mathrm{~b}$ & $0.34 \mathrm{~b}$ & $0.14 \mathrm{a}$ & $0.96 \mathrm{a}$ & $0.23 \mathrm{a}$ & $0.06 \mathrm{a}$ & $3.11 \mathrm{~b}$ \\
\hline $3 \mathrm{ppm} \mathrm{CPPU}^{a}$ & $1.69 \mathrm{~b}$ & $0.44 \mathrm{ab}$ & $0.00 \mathrm{a}$ & $1.15 \mathrm{a}$ & $0.12 \mathrm{a}$ & $0.02 \mathrm{a}$ & $3.42 \mathrm{~b}$ \\
\hline Seaweed extract & $3.18 \mathrm{a}$ & $0.17 \mathrm{~b}$ & $0.16 \mathrm{a}$ & $1.66 \mathrm{a}$ & $0.40 \mathrm{a}$ & $0.12 \mathrm{a}$ & $5.69 \mathrm{a}$ \\
\hline
\end{tabular}

*Means with the same letter in each column did not differ significantly $(P=0.05)$

${ }^{a} N$-(2-chloro-4-pyridinyl)- $N$ '-phenylurea

TABLE 7

Effect of treatments on defects of Redglobe from Tebogo in Limpopo province after six weeks (five weeks at $-0.5^{\circ} \mathrm{C}$ plus one week at $7.5^{\circ} \mathrm{C}$ ) of cold storage $(2008 / 2009)$.

\begin{tabular}{|c|c|c|c|c|c|c|c|}
\hline Treatment & $\begin{array}{c}\text { Total loose } \\
\text { berries } \\
(\%)\end{array}$ & $\begin{array}{c}\mathrm{SO}_{2} \text { damage } \\
(\%)\end{array}$ & $\begin{array}{l}\text { Decay } \\
(\%)\end{array}$ & $\begin{array}{c}\text { Split berries } \\
(\%)\end{array}$ & $\begin{array}{c}\text { Soft tissue } \\
\text { breakdown } \\
(\%)\end{array}$ & $\begin{array}{c}\text { Bruises } \\
(\%)\end{array}$ & $\begin{array}{c}\text { Total } \\
\text { defects } \\
(\%)\end{array}$ \\
\hline Control & $0.00 \mathrm{~b}^{*}$ & $3.85 \mathrm{a}$ & $0.05 \mathrm{a}$ & $0.27 \mathrm{~b}$ & $0.11 \mathrm{~b}$ & $0.04 \mathrm{a}$ & $4.32 \mathrm{a}$ \\
\hline $3 \mathrm{ppm} \mathrm{CPPU}^{a}$ & $0.48 \mathrm{ab}$ & $4.12 \mathrm{a}$ & $0.08 \mathrm{a}$ & $0.66 \mathrm{ab}$ & $0.86 \mathrm{a}$ & $0.04 \mathrm{a}$ & $6.24 \mathrm{a}$ \\
\hline $4 \mathrm{ppm} \mathrm{CPPU}^{a}$ & $0.45 \mathrm{ab}$ & $4.47 \mathrm{a}$ & $0.00 \mathrm{a}$ & $1.66 \mathrm{a}$ & $0.43 \mathrm{ab}$ & $0.00 \mathrm{a}$ & $7.01 \mathrm{a}$ \\
\hline $5 \mathrm{ppm} \mathrm{CPPU}^{a}$ & $0.69 \mathrm{a}$ & $2.20 \mathrm{a}$ & $0.00 \mathrm{a}$ & $0.90 \mathrm{ab}$ & $0.29 \mathrm{ab}$ & $0.00 \mathrm{a}$ & $4.08 \mathrm{a}$ \\
\hline Seaweed extract & $0.27 \mathrm{ab}$ & $6.37 \mathrm{a}$ & $0.00 \mathrm{a}$ & $0.49 \mathrm{~b}$ & $0.50 \mathrm{ab}$ & $0.04 \mathrm{a}$ & $7.67 \mathrm{a}$ \\
\hline
\end{tabular}

*Means with the same letter in each column did not differ significantly $(P=0.05)$

${ }^{a} N$-(2-chloro-4-pyridinyl)- $N$ '-phenylurea

TABLE 8

Effect of treatments on defects of Crimson Seedless from Roepersfontein in the Northern Cape province (2008/2009) after six weeks (five weeks at $-0.5^{\circ} \mathrm{C}$ plus one week at $7.5^{\circ} \mathrm{C}$ ) of cold storage $(2008 / 2009$ ).

\begin{tabular}{|c|c|c|c|c|c|c|c|}
\hline TREATMENT* & $\begin{array}{c}\text { Total loose } \\
\text { berries } \\
(\%)\end{array}$ & $\begin{array}{c}\mathrm{SO}_{2} \text { damage } \\
(\%)\end{array}$ & $\begin{array}{c}\text { Decay } \\
(\%)\end{array}$ & $\begin{array}{c}\text { Split berries } \\
(\%)\end{array}$ & $\begin{array}{c}\text { Soft tissue } \\
\text { breakdown } \\
(\%)\end{array}$ & $\begin{array}{c}\text { Bruise } \\
(\%)\end{array}$ & $\begin{array}{c}\text { Total } \\
\text { defects } \\
(\%)\end{array}$ \\
\hline Control & $1.57 \mathrm{a}^{*}$ & $0.74 \mathrm{bc}$ & $0.14 \mathrm{a}$ & $1.33 \mathrm{a}$ & $0.14 \mathrm{a}$ & $0.48 \mathrm{~b}$ & $4.40 \mathrm{~b}$ \\
\hline $2 \mathrm{ppm} \mathrm{CPPU}^{a}$ & $1.47 \mathrm{a}$ & $0.87 \mathrm{bc}$ & $0.02 \mathrm{a}$ & $3.71 \mathrm{a}$ & $0.00 \mathrm{a}$ & $0.59 \mathrm{~b}$ & $6.66 \mathrm{ab}$ \\
\hline $3 \mathrm{ppm} \mathrm{CPPU}^{a}$ & $2.18 \mathrm{a}$ & $1.27 \mathrm{ab}$ & $0.10 \mathrm{a}$ & $2.20 \mathrm{a}$ & $0.09 \mathrm{a}$ & $1.32 \mathrm{ab}$ & $7.16 \mathrm{ab}$ \\
\hline $4 \mathrm{ppm} \mathrm{CPPU}^{a}$ & $1.50 \mathrm{a}$ & $1.88 \mathrm{a}$ & $0.09 \mathrm{a}$ & $3.12 \mathrm{a}$ & $0.11 \mathrm{a}$ & $1.77 \mathrm{a}$ & $8.47 \mathrm{a}$ \\
\hline Seaweed extract & $1.64 \mathrm{a}$ & $0.28 \mathrm{c}$ & $0.02 \mathrm{a}$ & $3.28 \mathrm{a}$ & $0.03 \mathrm{a}$ & $0.94 \mathrm{ab}$ & $6.19 \mathrm{ab}$ \\
\hline
\end{tabular}

*Means with the same letter in each column did not differ significantly $(P=0.05)$

${ }^{a} N$-(2-chloro-4-pyridinyl)- $N$ '-phenylurea

these significantly (Table 8). Five ppm CPPU increased the percentage of loose berries of Redglobe. This effect of the combined use of $\mathrm{GA}_{3}$ and CPPU on loose berries of Redglobe corresponds to the findings of Zoffoli et al. (2009). On the other hand, Ben-Arie et al. (1997) found that the combined application of $\mathrm{GA}_{3}$ and CPPU on Thompson Seedless decreased the number of loose berries per box significantly compared to the use of only $\mathrm{GA}_{3}$. In this study, the percentage of split berries on Redglobe was increased significantly by 4 ppm CPPU, whereas Zoffoli et al. (2009) reported no significant increase in the percentage of split berries on Redglobe with the combined use of $\mathrm{GA}_{3}$ and CPPU.

\section{CONCLUSIONS}

The results of one season indicated that CPPU could be included, in combination with $\mathrm{GA}_{3}$, as part of a berry enlargement programme for Flame Seedless, Redglobe and Crimson Seedless. The seaweed extract was not effective in increasing berry size in any of the cultivars. However, a seaweed extract was effective in increasing the anthocyanin concentration of Flame Seedless berries and the berry firmness of both Flame Seedless and Crimson Seedless.

CPPU dosages of 2, 5 and 3 ppm improved the berry size of Flame Seedless, Redglobe and Crimson Seedless respectively. None of these treatments had a negative effect on other grape quality variables, except for $3 \mathrm{ppm} C P P U$, 
which increased TTA and decreased the anthocyanin concentration of Crimson Seedless. The lighter coloured Crimson Seedless grapes were still suitable for export. Although CPPU decreased the anthocyanin concentration of Crimson Seedless in the LOR, the detrimental effects of high temperature on anthocyanin concentration and grape colour should also be considered.

To be able to make final recommendations, the trials should be repeated for at least one more season to verify the results.

\section{LITERATURE CITED}

Anon., 2007. CPPU. In: Greyling, M. (ed). Guidelines for preparing export table grapes. Capespan Ltd., Belville, South Africa. p. 7.

ARC-ISCW, 2008. Private Bag X79, Pretoria, South Africa, 0001.

Avenant, J.H. \& Avenant, E., 2006. Effect of gibberellic acid and CPPU on colour and berry size of 'Redglobe' grapes on two soil types. Acta Hort. 727, 371-379.

Ben-Arie, R., Sarig, P., Cohen-Adhut, Y., Zutkhi, Y., Sonego, L., Kapulonov, T. \& Lisker, N., 1997. CPPU and GA effects on pre- and post-harvest quality of seedless and seeded grapes. Acta Hort. 463, 349-357.

Dokoozlian, N.K., Moriyama, M.M. \& Ebisuda, N.C., 1994. Forchlorfenuron (CPPU) increases the berry size and delays the maturity of Thompson Seedless table grapes. In: Rantz, J.M. \& Lewis, K.B. (eds). Proc. Int. Symp. Table Grape Production, American Society for Enology and Viticulture, June 1994, Anaheim, California, USA. pp. 63-68.

Greyling, M., (ed). 2007. Guidelines for preparing export table grapes. Capespan Ltd., Bellville, South Africa.
Iland, P.G., Ewart, A., Sitters, J., Markides, A. \& Bruer, N., 2000. Techniques for chemical analysis and quality monitoring during winemaking. Patrick Iland, Adelaide.

Kok, D., Bal, E., Celik, S., Ozer, C. \& Karauz, A., 2010. The influences of different seaweed doses on table quality characteristics of cv Trakya Ilkeren (Vitis Vinifera L.). Bulg. J. Agric. Sci. 16, 429-435.

Lázlo, J.C. \& Loubser, J.T., 1995. Optimum harvesting stage for Dawn Seedless, Festival, Sunred Seedless and Red Globe table grape cultivars. Decid. Fruit Grow. 45, 190-194.

McCullagh, P. \& Nelder, J.A., 1989 ( $2^{\text {nd }}$ ed). Generalized linear models. Chapman Hall, New York.

Mori, K., Goto-Yamamoto, N., Kitayama, M. \& Hashizume, K., 2007. Loss of anthocyanins in red-wine grape under high temperature. J. Exp. Bot. 58, 1935-1945.

Mori, K., Sugaya, S. \& Gemma, H., 2005. Decreased anthocyanin biosynthesis in grape berries grown under elevated night temperature condition. Scienta Hort. 105, 319-330.

Norrie, J., Branson, T. \& Keathley, P.E., 2002. Marine plant extracts impact on grape yield and quality. Acta Hort. 594, 315-319.

Peppi, M.C. \& Fidelibus, M.W., 2008. Effects of forchlorfenuron and abscisic acid on the quality of Flame Seedless grapes. HortSci. 43, 173-176.

Shapiro, S.S. \& Wilk, M.B., 1965. An analysis of variance test for normality (complete samples). Biometrika 52, 591-611.

South Africa, 1990. Standards and requirements regarding control of the export of table grapes. Department of Agriculture, Forestry and Fisheries, Cape Town.

Zoffoli, J.P., Latorre, B.A. \& Naranjo, P., 2009. Preharvest applications of growth regulators and their effect on postharvest quality of table grapes during cold storage. Postharvest Biol. Tech. 51, 183-192. 